\title{
An 82-Years-Old Woman with Diabetes Mellitus Type 2, Systemic Hypertension and Dyspnea, Admitted to Hospital with Right Lung Post Viral Pneumonia- A Case Report
}

\author{
Ema Lumi ${ }^{1}$, Prof asc. Thanas Furreraj ${ }^{2}$, Prof. Dr. Agron Ylli ${ }^{3}$ \\ ${ }^{1}$ Endocrinologist,Department of Internal Medicine, Regional Hospital" Teni Konomi", Korce, Albania \\ ${ }^{2}$ Associate Professor, Endocrinologist, Endocrine Department, UHC Mother Teresa, Tirana, Albania \\ ${ }^{3}$ Endocrinologist, Head of Endocrine Department, UHC Mother Teresa, Tirana, Albania
}

\begin{abstract}
Aim: Presentation of a case with diabetes mellitus type 2 and viral pneumonia, in an old woman. Clinical case: An 82-years old woman was brought to the emergency department with nausea, vomiting, fatigue, temperature, dyspnea and oliguria. The patient had a medical history of type 2 diabetes for five years and systemic hypertension for ten years, and she was under treatment with oral antidiabetic and antihypertensive drugs. Physical exam and Laboratory data: The blood pressure was 200/100 $\mathrm{mm} \mathrm{Hg}$, the heart rate was 110 beats/minute, the respiratory rate $28 / \mathrm{min}$. Temperature of $37.8^{\circ} \mathrm{C}$.The chest examination revealed tachypnea, decreased breath sounds, crackles in the bases of both lungs. Oxygen saturation was $78 \%$. The abdominal examination was unremarkable. She has edema of the lower extremities. Glucose $=500 \mathrm{mg} / \mathrm{dl}$, Creatinine $=1.47 \mathrm{mg} / \mathrm{dl}, A S T=287 \mathrm{U} / \mathrm{L}, A L T=318 U / L$, Hepatic virus $B$ and C antigensnegative. Brucellosis test, D-Dimer negative. Leukocytosis, first with left than right deviation of the leukocyte formula, high ESR and PCR. Thyroid function test not remarkable for hyperthyreosis. The urine, blood and culture were negative. Sputum stains and cultures were negative. The PPD test was negative. Chest $X$-ray indicated a dilated heart and bilateral pleural effusion. Computed tomographic (CT) scan of the chest showed pleural effusion and calcification in the right lung. Examination of the pleural fluid=1xudates. Conclusion: The diagnosis of viral pneumonia with bacterial superinfection of the right lung was given, relying on clinical feature and laboratory findings. The patient underwent treatment with Oxygen therapy, Fluids, Insulin, Antibiotics, Antiviral, Antyhepertensive and antimycotic drugs. She recovered after 14 days and discharged.
\end{abstract}

Keywords: Diabetes Mellitus type 2, Viral pneumonia, Influenza Virus type A, Hypertension, Urinary tract infection.

\section{Introduction}

Patients with diabetes mellitus are likely to develop many types of infections. Diabetes increases the susceptibility to different kinds of respiratory infections, and is often identified as an independent risk factor for developing lower respiratory tract infections. Pulmonary infections due to Streptococcus pneumonia or influenza virus may be associated with increased morbidity and mortality. Hospitalization of patients with diabetes due to influenza virus or flu-like infections is up to 6 times more likely to occur compared to healthy individuals, also diabetic patients are more likely to be hospitalized due to infection complications(1).

Recent investigations have demonstrated viruses to play a larger role, causing $13-50 \%$ of pathogen-diagnosed community-acquired pneumonia cases as sole pathogens and $8-27 \%$ of cases as mixed bacteria-virus infections. Influenza virus types $\mathrm{A}$ and $\mathrm{B}$ account for more than $50 \%$ of all community-acquired viral pneumonias in adults. $(2,3,4,5)$

The impact of influenza is high in elderly persons and greatest for those with chronic illnesses. It has been estimated that at least $63 \%$ of the 300,000 influenza-related hospitalizations and $85 \%$ of 36,000 influenza-related deaths occur in patients aged 65 years or older, despite the fact that this group accounts for only $10 \%$ of the population (6).
The influenza viruses are enveloped, single-stranded, RNA viruses of the family Orthomyxoviridae and are the most common viral cause of pneumonia. Three serotypes of influenza virus exist: A, B, and C. Influenza type A is usually the most virulent pathogen (7).

Hospitalization for pneumonia in middle-aged and older adults is also associated with subsequent risk for cardiovascular disease (CVD), according to a case-control study in JAMA (8).

\section{Case Report}

An 82-years old woman was brought to the emergency department with nausea, vomiting, fatigue, dyspnea and oliguria for the past twenty-four hours. The family reported that the patient had a medical history of type 2 diabetes for five years and systemic hypertension for ten years. Since then she was treated with Glibenclamide, Metformin, Enalapril, and Amlodipin. The patient has been in her usual state of health, with diabetes mellitus for more than one year until approximately two weeks earlier, when intermittent cough developed and her condition began to worsen.

On physical examination in the emergency department, the blood pressure was 200/100 mm Hg, the heart rate (Hr) was 110 beats per minute, the respiratory rate $(\mathrm{Rr}) 28 / \mathrm{min}$. She had a temperature of $37.8^{\circ} \mathrm{C}$ and her conscience was clear. 


\section{International Journal of Science and Research (IJSR) \\ ISSN (Online): 2319-7064 \\ Index Copernicus Value (2013): 6.14 | Impact Factor (2014): 5.611}

The chest examination revealed tachypnea, dullness to percussion and crackles in the bases of both lungs. Oxygen saturation was $78 \%$. The abdominal examination was unremarkable. She has edema of the lower extremities. Normal pulse in arteries of inferior extremities.

She underwent full examinations which demonstrated:

Chest X-ray indicated a dilated heart and minimal bilateral pleural effusion .( Figure 1.)

Electrocardiographic (EKG) findings and abdominal ultrasound indicated nothing remarkable.

Echocardiography revealed hypertrophic cardiomyopathy.

Specimens of blood, urine, and sputum were cultured, while the laboratory tests are shown in Table 1.

Urine test : $\mathrm{pH}=6.0$,proteins $0.66 \mathrm{~g} \%$, many WBC, 3-4 $\mathrm{RBC}$, glucose-positive, ketones-negative, indicating an urinary tract infection.

Intravenous fluids and glucose, insulin subcutaneous, furosemid intravenous and ampicillin were administered, The dose of insulin was adjusted according glucose levels. Enalapril, Amlodipin and oral anti diabetics was stopped, other medications as Olmesartan, Clopidogrel, and oral Nitrites were added. She was put in Oxygen therapy with facial mask intermittently.

On the next day the patient's physical status deteriorate. She complained of chest pain and dyspnea. Her 24-hour diuresis was $600 \mathrm{ml}$. On physical examination TA=160/90 mm/Hg, $\mathrm{Hr}=100 / \mathrm{min}, \mathrm{Rr}=25$, Oxygen saturation fall to $65 \%$. Additional diagnostic tests were performed and emergent consultation with the cardiologist and pneumologist was required.

\section{Electrocardiographic findings were still normal.}

Repeated Chest X-ray indicated bilateral pleural effusion with predominance in left lung(near $350 \mathrm{ml}$ ).

A diagnosis of cardio-respiratory insufficiency and bilateral bronchopneumonia had been given. The infusion of intravenous nitroglycerin begun.Treatment with broadspectrum antibacterial agents was limited because of very high levels of liver function tests. Ciprofloxacin intravenous was added to Ampicillin. Continuous positive airway pressure was given, and led to temporary improvement.

D-Dimer was in the upper limit of normal range, so a pulmonary embolism from a deep venous thrombosis was ruled out (9). Hepatic virus B and C antigens-negative. Brucellosis test was negative.

Thyroid function test were performed: $\mathrm{TSH}=0.187 \mathrm{mUI} / \mathrm{ml}$ (0.27-4.2), FT4=23.94 pmol/l(12-22), not remarkable for hyperthyreosis.

On the following days the patient status did not improved. She had inaudible breath sounds on the right lung.
Chest X-ray detected pleural effusions, whitish areas at the right lung base.

On the fifth day Computed tomographic (CT) scans of the chest, abdomen, and pelvis after the administration of contrast material, and liquids in order to prevent renal complications, was performed. It showed normal abdomen, no hepatic lesions, no mediastinal or abdominal lymphadenopathy ,but pleural effusion and calcification in the right lung. The CT scans also showed osteoporosis of the vertebral column. Figure 3.

During this hospitalization, intermittent episodes of hypoxemia occurred that were treated with oxygen therapy. Although lung cancer is common in the elderly, this patient has not multiple risk factors for the development of lung cancer, (she was non-smoking), the lack of a discrete mass or nodule on imaging studies lessens the likelihood of this diagnosis(10). Finally, her sudden course is not consistent with most malignant tumors.

During hospitalization, Urine tests revealed again an urinary tract infection. Liver function test continued to raise. The temperature was $37-37.4^{\circ} \mathrm{C}$. The urine, blood and culture were negative. Sputum stains and cultures were negative. The PPD test was negative.

Despite an extensive evaluation, no pathogen was identified. A thoracentesis was performed to examine the pleural fluid. The results were: Test of Rivalta pozitive, Albumin $3.9 \mathrm{~g} \%$, 2-3 WBC, 3-4 RBC, which goes for an exudative effusion(11).

A viral test was ordered. The results were : Virus Influenza A-positive, Virus A(H1N1)pdm09- negative.

Finally, relying more in clinical aspect of the patient, the diagnosis of viral pneumonia with bacterial superinfection of the right lung was suspected .

The antibiotics were switched to Cefepime and Moxifloxacin intravenous and small doses of Oseltamivir was given. An antimycotic drug, and Ferrous sulfate were added. Plasma transfusion was started as total protein fall, and the patient had anorexia. Antihypertensive drugs and Clopidogrel were continued. After three days the nitroglycerin $\mathrm{i} / \mathrm{v}$ was stopped.

On the following days ,the temperature fall to $36.8-37^{\circ} \mathrm{C}$, the patients condition ameliorated. She had neither dyspnea, nor tachycardia. Kidney function return to normality. The liver function tests became normal. Infection's markers fell down. Final chest $\mathrm{x}$-rays is shown in Figure 2.

The patient was switched to oral antibiotics on day 12, and on day 14 she was discharged to her home, on medication: Insulin, Antihypertensive drugs, Ferrous sulfate. While at home the patient resume previous activities. One month later she came to policlinic for her usual visit. The diabetes was well balanced, the arterial tension in normal values. The examination of the lungs revealed normal breathing, no pathological sounds. 


\section{International Journal of Science and Research (IJSR) \\ ISSN (Online): 2319-7064}

Index Copernicus Value (2013): 6.14 | Impact Factor (2014): 5.611
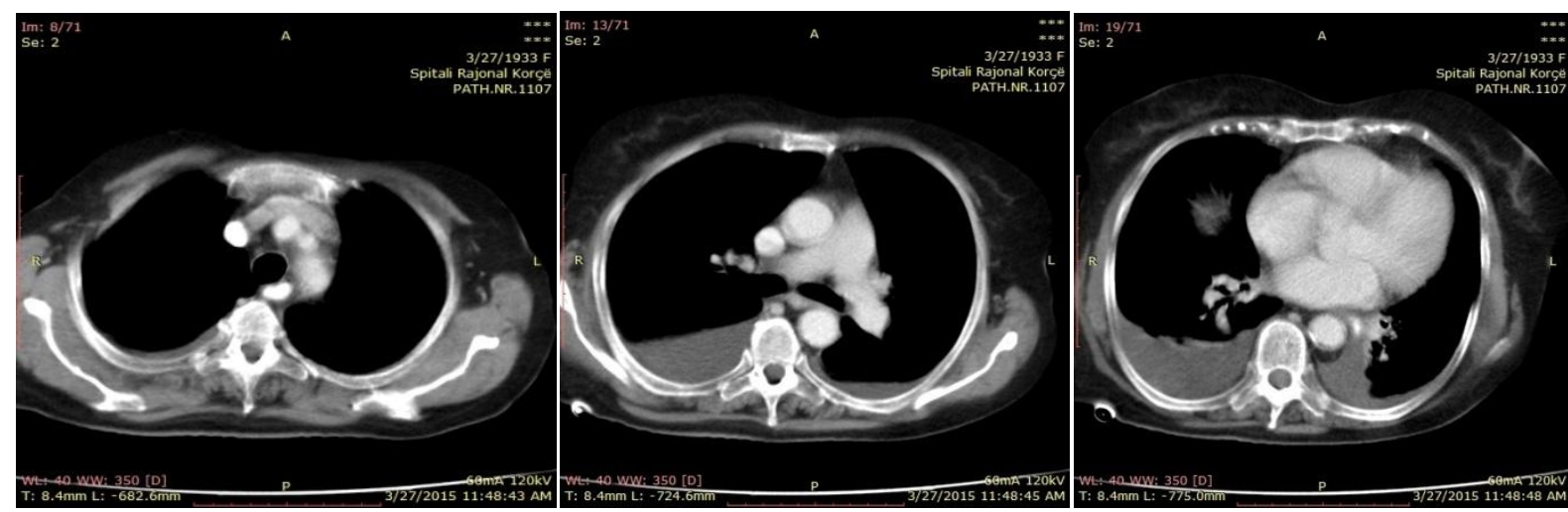

Figure 3: Ct scan of chest.

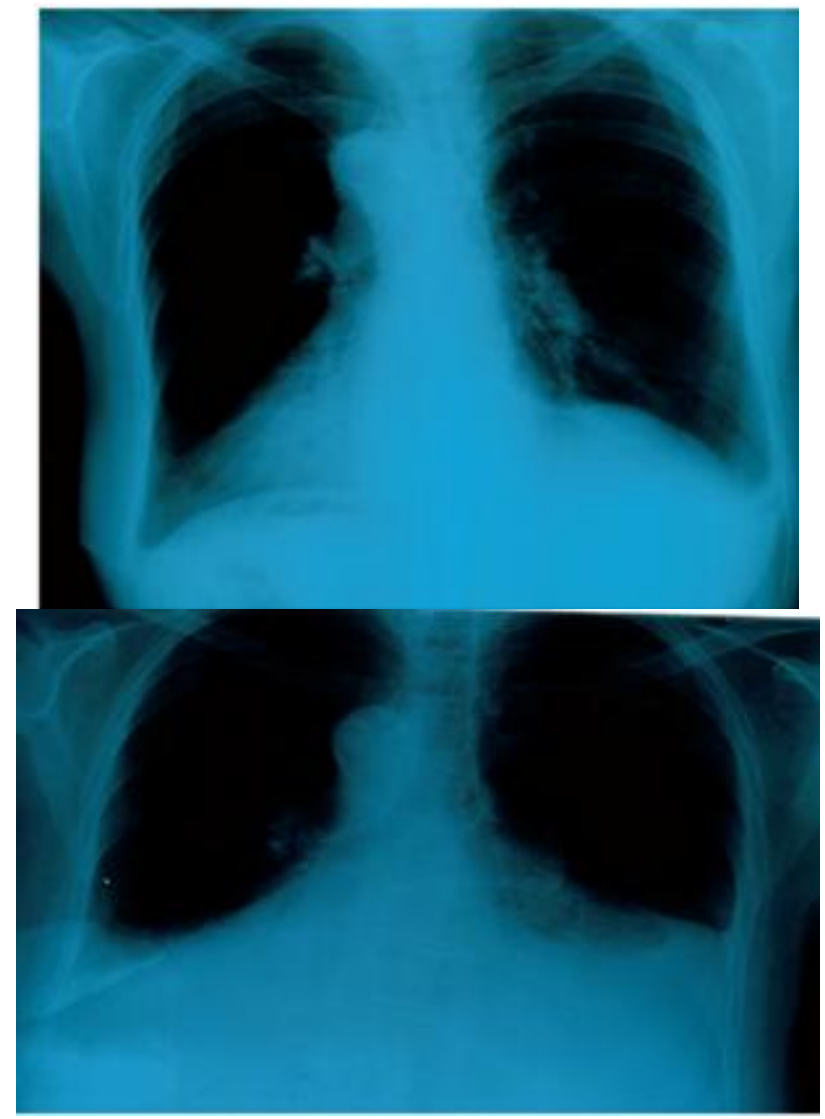

Figure 1 and 2: Chest X-Rays.

\begin{tabular}{|c|c|c|c|c|}
\hline $\begin{array}{c}\text { Table } 1 . \\
\text { Laboratory data }\end{array}$ & & & & \\
\hline Variable & $\begin{array}{c}\text { Reference } \\
\text { range,adults }\end{array}$ & $\begin{array}{c}\text { On } \\
\text { admission } \\
\end{array}$ & Day 5 & Day 14 \\
\hline Glucose (mg/dl) & $70-100$ & 500 & 280 & 118 \\
\hline Creatinine (mg/dl) & $0.6-1.21$ & 1.47 & 1.9 & 1.5 \\
\hline ALT (U/L) & $0-46$ & 287 & 456 & 33 \\
\hline AST (U/L) & $0-46$ & 318 & 301 & 60 \\
\hline $\begin{array}{l}\text { Bilirubin total } \\
(\mathrm{mg} / \mathrm{dl})\end{array}$ & $0.4-1.0$ & 0.74 & 2.6 & 1.2 \\
\hline Protein total (g/dl) & $\leq 8$ & 6.1 & 5.9 & 6.1 \\
\hline $\begin{array}{c}\text { Alkaline } \\
\text { phosphatase (U/L) }\end{array}$ & $90-280$ & 143 & 180 & 180 \\
\hline $\begin{array}{c}\text { Creatine kinase } \\
(\mathrm{U} / \mathrm{L})\end{array}$ & $0-171$ & 40 & 50 & 55 \\
\hline Fibrinogen (mg/dl) & $0-400$ & 490 & - & 492 \\
\hline Troponine & & negative & negative & negative \\
\hline $\begin{array}{c}\text { Glycated } \\
\text { hemoglobin A1c (\%) }\end{array}$ & $4.5-6.2$ & 8.1 & - & - \\
\hline Calcium (mg/dl) & $8-10$ & 8.5 & 8.2 & 8 \\
\hline
\end{tabular}

\begin{tabular}{|c|c|c|c|c|}
\hline Potassium mmol/l & $3.4-4.8$ & 4.7 & 3.8 & 4.0 \\
\hline Sodium( $\mathrm{mmol} / \mathrm{l})$ & $135-145$ & 140 & 137 & 145 \\
\hline $\begin{array}{l}\text { White-cell count } \\
\text { (per } \mathrm{mm}^{3} \text { ) }\end{array}$ & $3.5-10.0$ & 12,600 & 14,000 & 9,900 \\
\hline $\begin{array}{l}\text { Red-cell count (per } \\
\mathrm{mm}^{3} \text { ) }\end{array}$ & $3.8-5.8 \times 10^{6}$ & $3.45 \times 10^{6}$ & $\begin{array}{l}3.17 \\
\times 10^{6} \\
\end{array}$ & $3.1 \times 10^{6}$ \\
\hline Hemoglobin (g/dl) & $11.0-16.5$ & 8.5 & 8.2 & 8 \\
\hline Hematocrit (\%) & $35.0-50.0$ & 28.9 & 27.4 & 30 \\
\hline $\begin{array}{c}\text { Platelet count(per } \\
\mathrm{mm}^{3} \text { ) }\end{array}$ & $\begin{array}{l}150,000- \\
390,000\end{array}$ & 381,000 & 448,000 & 351,000 \\
\hline \multicolumn{5}{|l|}{$\begin{array}{c}\text { Differential count } \\
(\%)\end{array}$} \\
\hline Lymphocites (\%) & $17.0-48.0$ & 9.8 & 16.1 & 15.0 \\
\hline Monocites (\%) & $4.0-10.0$ & 9.0 & 15.9 & 17.0 \\
\hline Eosinophils ( \%) & $43-76.0$ & 81.2 & 68.0 & 68.0 \\
\hline $\operatorname{MCV}\left(\mu \mathrm{m}^{3}\right)$ & $80-97$ & 84 & 86 & 88 \\
\hline Iron $(\mu \mathrm{g} / \mathrm{dl})$ & $40-160$ & 55 & - & 60 \\
\hline $\begin{array}{c}\text { Total } \\
\text { cholesterol(mg/dl) }\end{array}$ & $10-240$ & 306 & - & 300 \\
\hline $\begin{array}{l}\text { Triglycerides } \\
\text { (mg/dl) }\end{array}$ & $40-160$ & 183 & - & 180 \\
\hline INR & $1-2$ & 1.8 & 2 & 2 \\
\hline Protein $\mathrm{C}$ reactive & $\leq 5$ & 22 & 37 & 15 \\
\hline ESR (mm/h) & $8-15$ & 35 & 55 & 40 \\
\hline
\end{tabular}

\section{Discussion}

Virus Influenza is a substantial cause of morbidity and mortality in diabetics. During epidemics of influenza pneumoniae, the rate of pneumonia, ketoacidosis and mortality increase sharply in diabetics (12). Death rates attributable to influenza may increase by $5 \%-15 \%$ during the epidemic, especially in elderly patients who have a coexisiting cardiovascular disease (13). Influenza infection predispose developing postinfluenza staphylococcal pneumonia, which has an associated mortality of $30 \%$ (14). Diagnostic approach of this case led us to the supportive fact that diabetic persons appear to be at an increased risk of lower respiratory tract infections. They are characterized by serious clinical features, longer duration, more frequent complications, and increased mortality (15). Our patient had the chance to be recovered, despite the concomitant illness and the poor prognosis.

\section{Conclusions}

Although diabetes is often identified as an independent risk factor for developing lower respiratory tract infections, the available literature is rare. Further studies might provide an insight into the basic mechanisms of the disease and allow

\section{Volume 5 Issue 3, March 2016}


the development of improved prophylaxis and treatment regimens for lower respiratory tract infections in diabetic patients (15). Immunization with influenza and antipneumococcal vaccines is recommended to reduce hospitalizations, deaths, and medical expenses (1).

\section{References}

[1] Pneumonol Alergol Pol. 2015;83(5):401-8. doi: 10.5603/PiAP.2015.0065.The etiology of lower respiratory tract infections in people with diabetes. Klekotka RB ${ }^{1}$, Mizgała E, Król W.

[2] Jennings LC, Anderson TP, Beynon KA, Chua A, Laing RT, Werno AM, et al. Incidence and characteristics of viral community-acquired pneumonia in adults. Thorax. 2008 Jan. 63(1):42-8. [Medline].

[3] Marcos MA, Camps M, Pumarola T, et al. The role of viruses in the aetiology of community-acquired pneumonia in adults. Antivir Ther. 2006. Vol. 11:351359.

[4] Templeton KE, Scheltinga SA, van den Eeden WC, Graffelman AW, van den Broek PJ, Claas EC. Improved diagnosis of the etiology of communityacquired pneumonia with real-time polymerase chain reaction. Clin Infect Dis. 2005 Aug 1. 41(3):345-51. [Medline].

[5] Johnstone J, Majumdar SR, Fox JD, Marrie TJ. Viral infection in adults hospitalized with communityacquired pneumonia: prevalence, pathogens, and presentation. Chest. 2008 Dec. 134(6):1141-8. [Medline].

[6] Whitney CG, Harper SA. Lower respiratory tract infections: prevention using vaccines. Infect Dis Clin North Am. 2004 Dec. 18(4):899-917. [Medline] )

[7] Viral Pneumonia Author: Zab Mosenifar, MD, FACP, FCCP; Chief Editor: Ryland P Byrd, Jr, MD

[8] Hospitalization for Pneumonia Linked to Increased Risk for Later Cardiovascular Disease By Amy Orciari Herman Edited by David G. Fairchild, MD, $M P H$, and Lorenzo Di Francesco, MD, FACP, FHM

[9] Wells PS, Anderson DR, Rodger M, Forgie M, Kearon C, Dreyer J. Evaluation of D-dimer in the diagnosis of suspected deep-vein thrombosis. N Engl J Med. 2003 Sep 25. 349(13):1227-35. [Medline]

[10] Gridelli C, Perrone F, Monfardini S. Lung cancer in the elderly. Eur J Cancer 1997;33:2313-2314.

[11] Light RW. Clinical practice. Pleural effusion. $N$ Engl $J$ Med. 2002 Jun 20. 346(25):1971-7.

[12] Bouter KP, Diepersloot RJ, Van-Romunde LK, et al. Effect of epidemic influenza on ketoacidosis. Diabetes Res Clin Pract 1991;12:61-65.

[13] Diepersloot RJ, Bouter KP, Hoekstra JB. Influenza infection and DM. Case for annual vaccination. Diabetes Care 1990;13:876-880.

[14] Woodhead M, Mac Farlane J, McCracken J, et al. Prospective study of the etiology and outcome of pneumonia in a community. Lancet 1987;1:671- 676.

[15]Ref) PULMONARY INFECTIONS IN DIABETES MELLITUS Spomenka Ljubiæ1, Ayyasamy Balachandran2, Ivana Pavliæ-Renar1, Ante Barada1, @eljko Metelko1 Diabetologia Croatica 33-4, 2004 